\title{
Irreversible Bronchial Goblet Cell Metaplasia in Hamsters with Elastase-Induced Panacinar Emphysema
}

\author{
Thomas G. Christensen, Agnes L. Korthy, Gordon L. Snider, and J. A. Hayes \\ From the Mallory Institute of Pathology, Boston City Hospital, and the Departments of Pathology \\ and Medicine, Boston University School of Medicine, Boston, Massachusetts 02118, and the Veterans \\ Administration Hospital, Boston, Massachusetts 02130
}

\begin{abstract}
A B S TRACT A single intratracheal instillation of pancreatic elastase in hamsters induces a lesion resembling human panacinar emphysema. This paper reports the occurrence of irreversible goblet cell metaplasia in the bronchial epithelium of hamsters similarly exposed to elastase. The goblet cell change was dose related; a dose of $0.1 \mathrm{mg} / 100 \mathrm{~g}$ body wt or less at 16 days, produced slight or moderate goblet cell metaplasia in fewer than half the animals, whereas $84 \%$ of animals treated with a dose between 0.2 and $0.5 \mathrm{mg} / 100$ g body wt developed goblet cell metaplastic lesions, more than half of which were considered to be severe. The percentage of goblet cells in the epithelium of elastase-treated hamsters (32.5) was significantly higher $(P<0.005)$ than that of unexposed $(12.2)$ and saline-exposed controls (18.7). All hamsters examined 6 and 12 mo after elastase treatment showed the lesion. The pathogenesis of the changes is unclear but the possibility is raised that the bronchial changes may be due to disturbance of an endogenous protease-antiprotease system. The findings suggest the hypothesis that, under appropriate circumstances, a single pulmonary insult in man could lead to a permanent lung injury demonstrating the anatomic lesions of both chronic bronchitis and panacinar emphysema.
\end{abstract}

\section{INTRODUCTION}

The increased frequency of severe panacinar emphysema in homozygous alpha-1-antitrypsin deficiency $(A T D)^{1}$ is a well documented clinical entity (1-5).

This work was presented in part to the American Federation for Clinical Research, Boston, Mass. January, 1976. Clin. Res. 1975. 23: 597. (Abstr.)

Received for publication 6 July 1976 and in revised form 17 November 1976.

${ }^{1}$ Abbreviations used in this paper: AM, alveolar macrophages; ATD, alpha-1-antitrypsin deficiency; BGH, bronchial
It has been suggested that the emphysematous process might result from the uninhibited action of elastase, or an elastase-like protease, liberated from polymorphonuclear leukocytes (PML) or alveolar macrophages (AM) within the lung (6-8). The intratracheal instillation of crystalline, porcine, pancreatic elastase in hamsters induces a lesion with many of the anatomic and physiologic features of human panacinar emphysema. An increase in total lung volume and mean linear intercept (MLI) occur as early as $4 \mathrm{~h}$ after such injections (9), and later stages of the injury show destruction of alveolar walls as manifest by a significant decrease in internal surface area. These morphologic changes are accompanied by an increase in compliance, functional residual capacity, lung volume at $-20 \mathrm{~cm} \mathrm{H}_{2} \mathrm{O}$ transpulmonary pressure (analogous to human residual volume), and lung volume at $25 \mathrm{~cm} \mathrm{H}_{2} \mathrm{O}$ transpulmonary pressure (analogous to total lung capacity) $(10,11)$. These abnormalities of structure and function have been proposed by Wright (12) as the criteria necessary for the development of an acceptable model of emphysema in experimental animals.

Further studies in our laboratories have demonstrated the simultaneous occurrence of irreversible bronchial goblet cell metaplasia in hamsters with elastase-induced emphysema and these observations form the basis for this report.

\section{METHODS}

Male golden hamsters (Mesocricetus auratus), weighing 100-140 g, were anesthetized with Brevital (methohexital sodium, Eli Lilly and Company, Indianapolis, Ind.), $5 \mathrm{mg} / 100$ $\mathrm{g}$ body wt, and the trachea was intubated under direct vision. A single intratracheal injection of crystalline, porcine, pancreatic elastase (Whatman, EC 3.4.4.7, activity $26.8 \mathrm{U} /$

gland hypertrophy; GCM, goblet cell metaplasia; $\mathrm{H}$ and E, hematoxylin and eosin; MLI, mean linear intercept; PAS, periodic acid-Schiff; PML, polymorphonuclear leukocytes. 


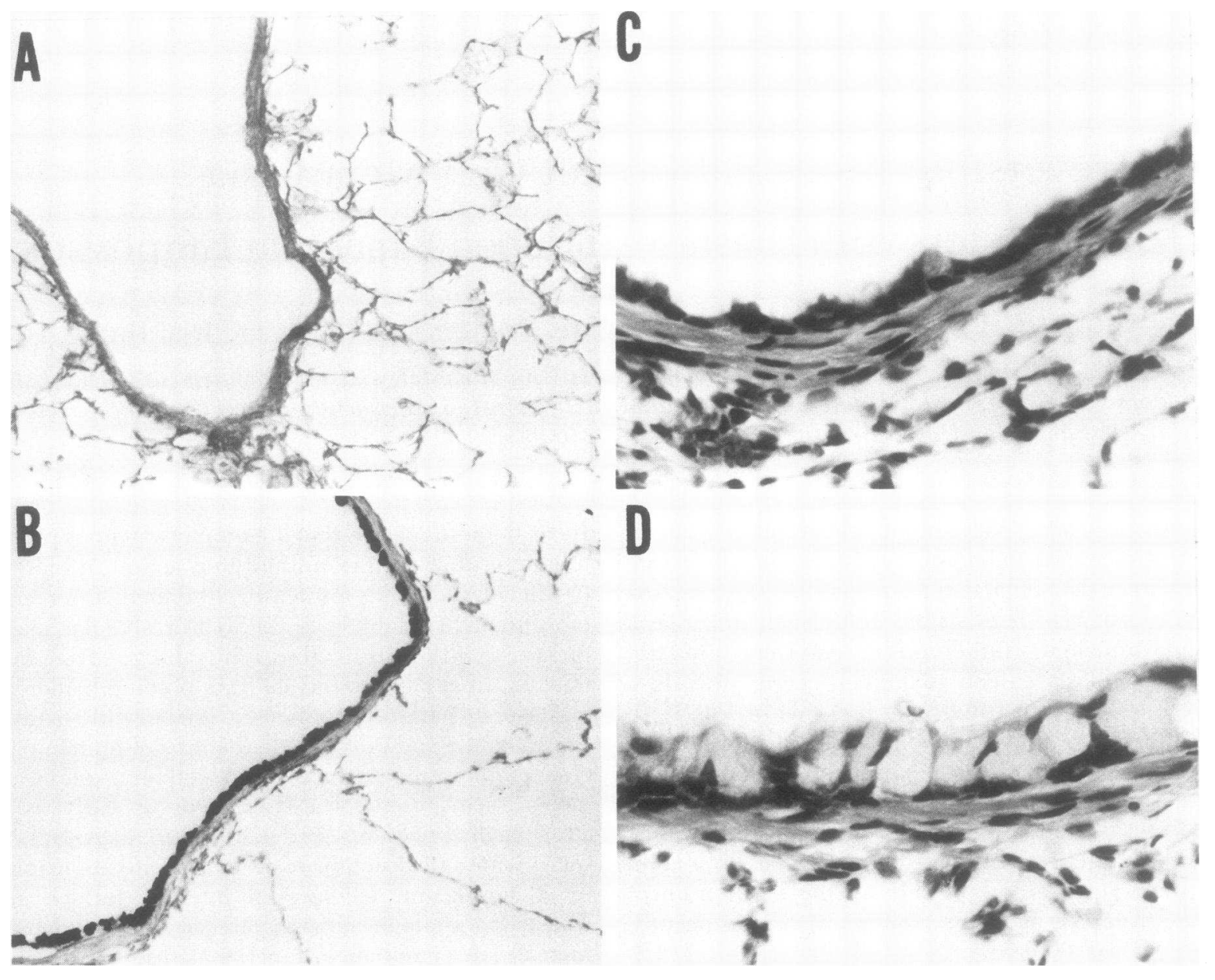

FIGURE 1 Photomicrographs demonstrating the effect of pancreatic elastase on hamster bronchial epithelium. (A) Untreated control stained with PAS showing no apparent goblet cells $(\times 130)$. (B) Elastase-treated animal killed $6 \mathrm{mo}$ after one dose of $0.2 \mathrm{mg} / 100 \mathrm{~g}$ body wt and stained with PAS to demonstrate severe GCM. Note also the enlarged air spaces in the emphysematous parenchyma $(\times 130)$. (C) $\mathrm{H}$ and E-stained specimen from a control hamster showing sparse content of goblet cells $(\times 510)$. (D) $\mathrm{H}$ and E-stained specimen from elastase-treated hamster 3 mo after exposure showing an excessive number of goblet cells bulging with secretory product $(\times 510)$.

mg) dissolved in physiological saline was administered in doses of $0.05,0.1,0.2,0.25,0.3,0.4$, or $0.5 \mathrm{mg} / 0.5 \mathrm{ml}$ per $100 \mathrm{~g}$ body wt. Unexposed animals and those anesthetized and injected with a comparable volume of physiological saline served as controls. Animals were killed 16 days after the start of the experiment by exsanguination after an overdose of barbiturate given intraperitoneally. Lungs were fixed after excision by intratracheal instillation of $10 \%$ neutral buffered formalin at a hydrostatic pressure of $25 \mathrm{~cm}$. Sagittal sections were taken from the parahilar area and $2-3 \mathrm{~mm}$ below the lateral pleurae. They were processed to paraffin embedding, sectioned at 5-10 $\mu \mathrm{m}$, and stained with hematoxylin and eosin ( $\mathrm{H}$ and $\mathrm{E}$ ) and elastic-Van Gieson stains, and the periodic acid-Schiff (PAS) reaction.

In a second experiment, animals treated with one dose of $0.2 \mathrm{mg}$ elastase $/ 100 \mathrm{~g}$ body wt and untreated control animals were killed at $4 \mathrm{~h}, 1,4,8,16$, and 42 days, 3,6 , and 12 mo after injection and prepared for histological examination as described above.
In the first two experiments, the distribution and proportion of goblet cells in the intrapulmonary bronchial epithelium were assessed in paraffin sections by two independent observers with a five point scale in which 0 represented no, 1-slight, 2-moderate, 3-severe, and 4-very severe goblet cell increase. This assessment was made by comparison with standard slides. The score was termed the goblet cell index. Evaluation of interobserver agreement on the goblet cell index was determined by Spearman Rank Correlation Analysis (13). Goblet cells were identified in $\mathrm{H}$ and $\mathrm{E}$ sections as cells with pale, often foamy cytoplasm, and no cilia. In slides stained with PAS, goblet cells were easily identified by the purple-red reaction product due to their content of mucus. Determinations of MLI were made on paraffin slides from treated and control animals with the method described previously (10).

In a third experiment, hamsters were injected once with $0.2 \mathrm{mg}$ of elastase $/ 0.5 \mathrm{ml}$ saline per $100 \mathrm{~g}$ body wt and killed $1,4,16$, and 24 days later by intravascular fixation via a 


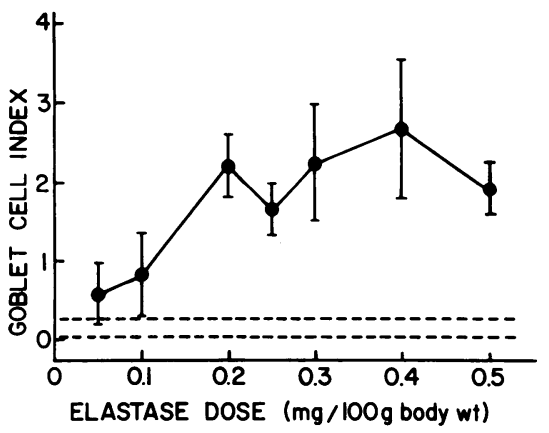

FIGURE 2 Effect of pancreatic elastase dose on the extent of GCM at 16 days in hamster bronchi. An index of 0 signifies normal numbers of goblet cells; 1 signifies slight metaplasia, 2-moderate, 3-severe, and 4-very severe metaplasia. Dashed lines represent the standard error about the mean for unexposed controls; filled circles represent mean values of goblet cell index for treated animals \pm SEM.

needle inserted into the right ventricle while the animals were anesthetized. Locke's solution at room temperature was perfused through the lungs for $5 \mathrm{~min}$ followed by $10 \mathrm{~min}$ of Karnovsky's fixative (14) diluted 1:3 with $0.2 \mathrm{M}$ cacodylate buffer, $\mathrm{pH}$ 7.4. The lungs were then removed and placed in containers of the same fixative overnight. The fixed lungs were sliced sagitally to reveal the major intrapulmonary bronchi. With a dissecting microscope, portions of the main stem bronchi and intrapulmonary airways with adjacent alveoli were cut transversely and removed as 1$\mathrm{mm}$ cubes and postfixed in $2 \%$ osmium tetroxide in $0.2 \mathrm{M}$ cacodylate buffer, $\mathrm{pH} 7.4$, for $1 \mathrm{~h}$ at room temperature. The tissues were dehydrated through a graded ethanol series, embedded in Epon-Araldite, sectioned at 1-2 $\mu \mathrm{m}$, and stained with methylene blue or basic fuchsin followed by alkaline methylene blue. Controls were untreated animals killed at 16 days and saline-treated animals $(0.5 \mathrm{ml} / 100 \mathrm{~g}$ body wt) killed at $6 \mathrm{~h}, 2,16,33$, and 180 days after exposure. Sections from the lungs of animals in this experiment were used to determine the percentage of goblet cells in the bronchial epithelium. Nonciliated cells which contained light- or dark-staining cytoplasmic droplets were scored as goblet cells. The number of goblet cells was expressed as a percentage of the total number of cells with a luminal border. All available sections with epithelium were used and a minimum of 600 total cells per animal was counted. The data in this experiment were analyzed by a double-tailed $t$ test for nonpaired variables (15).

\section{RESULTS}

Goblet cell increase of varying severity was observed in the bronchi of the majority of elastase-treated hamsters and this increase will subsequently be referred to as goblet cell metaplasia (GCM). The lesion was most prominent in the large intrapulmonary bronchi but goblet cells were also seen in distal airways where they do not normally occur. The metaplastic epithelium was taller, individual goblet cells larger, and the PAS reaction of goblet cells more intense in elastase-damaged hamsters than in controls (Fig. 1). In treated animals, detachment of the

TABLE I

Relationship between Goblet Cell Index and MLI in Hamsters with Elastase-Induced Lung Damage

\begin{tabular}{|c|c|c|c|c|c|c|}
\hline \multirow[b]{2}{*}{ Treatment } & \multirow{2}{*}{$\begin{array}{l}\text { Time of } \\
\text { killing }\end{array}$} & \multicolumn{5}{|c|}{ Goblet cell index* } \\
\hline & & 0 & 1 & 2 & 3 & 4 \\
\hline \multirow[b]{2}{*}{ Unexposed controls } & days & \multicolumn{5}{|c|}{$M L I \times 10^{-3} \mathrm{~cm} \ddagger$} \\
\hline & $42-365$ & $\begin{array}{c}6.3 \pm 0.1 \\
(26)\end{array}$ & $\begin{array}{c}6.3 \pm 0.4 \\
(2)\end{array}$ & $\begin{array}{l}7.0 \\
(1)\end{array}$ & - & - \\
\hline \multicolumn{7}{|c|}{ Elastase, $m g / 100 \mathrm{~g}$ body $w t$} \\
\hline 0.2 & $42-365$ & $\begin{array}{c}16.3 \\
(1)\end{array}$ & $\begin{array}{c}17.6 \pm 1.4 \\
(7)\end{array}$ & $\begin{array}{c}16.8 \pm 0.9 \\
(5)\end{array}$ & $\begin{array}{c}15.3 \pm 1.7 \\
(5)\end{array}$ & $\begin{array}{c}18.8 \pm 0.6 \\
(2)\end{array}$ \\
\hline 0.2 & 16 & $\begin{array}{r}11.8 \\
(1) \S\end{array}$ & - & $\begin{array}{c}14.1 \pm 1.4 \\
(2)\end{array}$ & $\begin{array}{c}12.2 \pm 0.9 \\
(6)\end{array}$ & - \\
\hline 0.5 & 16 & $\begin{array}{c}15.7 \pm 3.7 \\
(2)\end{array}$ & $\begin{array}{c}13.9 \pm 0.6 \\
(3) \S\end{array}$ & $\begin{array}{c}10.7 \pm 0.6 \\
(3)\end{array}$ & $\begin{array}{c}14.7 \pm 1.0 \\
(5)\end{array}$ & $\begin{array}{c}15.0 \\
(1)\end{array}$ \\
\hline Combined doses & $8-365$ & $\begin{array}{c}13.4 \pm 0.8 \\
(10)\end{array}$ & $\begin{array}{c}15.1 \pm 0.9 \\
(15)\end{array}$ & $\begin{array}{c}13.7 \pm 0.8 \\
(16)\end{array}$ & $\begin{array}{c}13.8 \pm 0.5 \\
(28)\end{array}$ & $\begin{array}{c}16.0 \pm 1.8 \\
(4)\end{array}$ \\
\hline 0.2 to $0.5^{\|}$ & & & & & & \\
\hline
\end{tabular}

* The goblet cell index indicates the severity of GCM on a scale of no(0), slight(1), moderate(2), severe(3), or very severe(4) metaplasia.

$\ddagger$ Each value signifies the mean \pm SEM of MLI data averaged from the number of animals in parentheses.

\$One additional animal was assigned to this category but a poorly inflated lung precluded MLI determination.

"Doses in this range were $0.2,0.25,0.3,0.4$, and $0.5 \mathrm{mg} / 100 \mathrm{~g}$ body wt. 


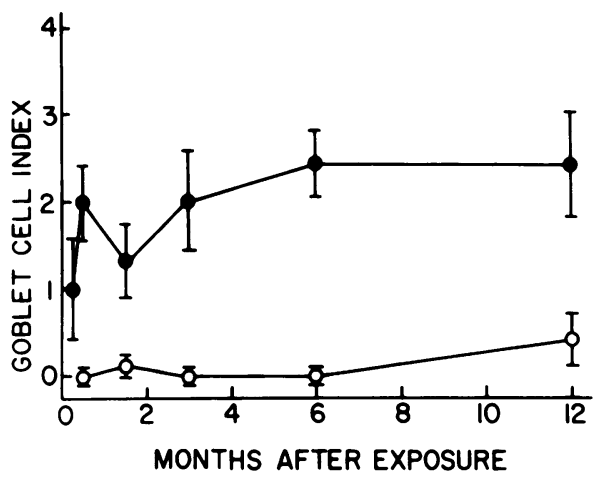

Figure 3 Progression of GCM assessed in paraffin sections of lungs from hamsters either unexposed (open circles) or treated with $0.2 \mathrm{mg}$ pancreatic elastase $/ 100 \mathrm{~g}$ body wt (closed circles). Mean values for goblet cell index and SEM are given.

epithelium from the submucosa was a frequent occurrence, particularly at higher doses of elastase but this was rarely found in the control hamsters. None of the animals showed any histologic evidence of infection.

The extent of GCM observed in paraffin sections at 16 days postinjection was related to the dosage of elastase (Fig. 2). Only 3 of 11 animals exposed to a dose of $0.1 \mathrm{mg} / 100 \mathrm{~g}$ body wt or less exhibited any GCM and the change was slight or moderate in severity. In contrast, $84 \%$ of the animals treated with $0.2-0.5 \mathrm{mg}$ elastase $/ 100 \mathrm{~g}$ body wt and killed at 16 days developed lesions, with $20 \%$ showing slight change, $16 \%$ moderate change, $43 \%$ severe, and $5 \%$ very severe GCM. Irrespective of the dose of elastase or time of killing, there appeared to be little correlation between the extent of GCM and severity of emphysema as assessed by values for MLI. Table I shows a summary of the data in support of this conclusion. $^{2}$

The evolution of the lesion with time caused by a single dose of $0.2 \mathrm{mg}$ elastase $/ 100 \mathrm{~g}$ body wt is illustrated in Fig. 3. GCM was first observed in paraffin sections from two of four animals killed 8 days after elastase treatment. At 16 days, 8 of 10 animals had moderate or severe GCM and by 3 mo the percentage of hamsters demonstrating lesions had increased to $100 \%$, a change which persisted to $12 \mathrm{mo}$.

\footnotetext{
${ }^{2}$ Supplemental material, two pages, has been deposited with the National Auxiliary Publications Service (NAPS) as NAPS document 02946. This information may be ordered from ASIS/NAPS, c\% Microfiche Publications, 305 East 46th Street, New York 10017. Remit with order for each NAPS document number $\$ 1.50$ for microfiche or $\$ 5.00$ for photocopies for up to 30 pages; for each additional page over the first 30 pages, there is a $15 \propto$ charge per page. Checks should be made payable to Microfiche Publications.
}

The parenchymal lesion as measured by MLI was as severe at 6 and $12 \mathrm{mo}$ as it was at $3 \mathrm{mo}$, as originally described (10). Excellent interobserver agreement was obtained for the values of goblet cell index of treated and control animals as tested by the Spearman Rank Correlation $\left(r_{s}=0.89, t=11.9, P\right.$ $<0.001)$.

The quantitative assessment of GCM with plasticembedded tissues is shown in Table II. The resolution of morphologic detail obtained with tissue embedded in plastic was much superior to that of tissue embedded in paraffin and goblet cells were easily identified by increased numbers of secretory droplets and absence of cilia (Fig. 4); as a result, lesions were observed for the first time at 1 day in plastic sections as compared with 8 days in paraffin sections. Saline-exposed animals had a significantly higher percentage of goblet cells $(18.7 \%)$ than unexposed hamsters $(12.2 \%)$ up to 16 days postinjection, but subsequently these values fell to normal levels. Elastase treatment resulted in a highly significant increase $(P$ $<0.005)$ in goblet cells as compared with untreated and saline-exposed animals. The two animals sacrificed one day postelastase injection had a mean of $31.6 \%$ goblet cells and this abnormal proportion of goblet cells remained approximately the same in animals killed at 4,16 , and 24 days after exposure.

\section{DISCUSSION}

Emphysema is defined in anatomic terms $(16,17)$ and anatomical and physiological criteria can be developed for animal models of the human disease (12). In contrast, human chronic bronchitis is defined in clinical terms as chronic sputum production for a specified duration (16) and in the strictest sense can have no animal counterpart. However, an increase in the bronchial mucus secreting apparatus seems acceptable as the pathological counterpart of human chronic bronchitis based on the observation that autopsy studies show that bronchial gland hypertrophy (BGH) occurs in a much higher proportion of persons with chronic bronchitis than in those without (18, 19). Although the frequency curve for $\mathrm{BGH}$ is unimodal and some persons with BGH have no bronchitis and some chronic bronchitics lack BGH (20), the general association between BGH and bronchitic symptoms is not disputed (21). The problem of correlating chronic bronchitis with animal models is further complicated by the absence of submucosal bronchial glands in small experimental animals, including the hamster. Consequently caution must be observed before accepting an animal model of human chronic bronchitis. However, we believe that goblet cells in the hamster are analagous to the combined submucosal glands and goblet cells of humans and hence, GCM in 
TABLE II

Effect of Elastase on Percentage of Goblet Cells in Bronchial Epithelium of Hamsters

\begin{tabular}{|c|c|c|c|c|}
\hline \multirow[b]{2}{*}{ Treatment } & \multirow{2}{*}{$\begin{array}{l}\text { Time of } \\
\text { killing }\end{array}$} & \multicolumn{2}{|c|}{ No. of cells counted per animal } & \multirow{2}{*}{$\begin{array}{l}\text { Percentage } \\
\text { goblet cells }\end{array}$} \\
\hline & & Goblet cells & Total & \\
\hline & dayss & & & \\
\hline \multirow{3}{*}{ Unexposed controls } & 16 & 184 & 1,411 & 13.0 \\
\hline & 16 & 79 & 702 & 11.3 \\
\hline & 16 & 208 & 1,703 & 12.2 \\
\hline Mean \pm SEM & & $157 \pm 40$ & $1,272 \pm 297$ & $12.2 \pm 0.49^{*}$ \\
\hline \multicolumn{5}{|l|}{ Saline controls } \\
\hline \multirow[t]{3}{*}{ Group I } & $1 / 4$ & 131 & 710 & 18.5 \\
\hline & 2 & 121 & 733 & 16.5 \\
\hline & 16 & 191 & 903 & 21.2 \\
\hline Mean \pm SEM & & $148 \pm 22$ & $782 \pm 61$ & $18.7 \pm 1.36$ \\
\hline \multirow[t]{4}{*}{ Group II } & 33 & 303 & 2,121 & 14.3 \\
\hline & 33 & 194 & 1,753 & 11.1 \\
\hline & 180 & 236 & 2,133 & 11.1 \\
\hline & 180 & 278 & 1,940 & 14.3 \\
\hline Mean \pm SEM & & $253 \pm 24$ & $1,987 \pm 90$ & $12.7 \pm 0.92$ \\
\hline \multirow[t]{7}{*}{ Elastase } & 1 & 619 & 1,686 & 36.7 \\
\hline & 1 & 181 & 685 & 26.4 \\
\hline & 4 & 232 & 769 & 30.2 \\
\hline & 16 & 712 & 2,209 & 32.2 \\
\hline & 16 & 481 & 1,219 & 39.5 \\
\hline & 24 & 276 & 844 & 32.7 \\
\hline & 24 & $\begin{array}{c}201 \\
386 \pm 82\end{array}$ & $\begin{array}{c}669 \\
1,154 \pm 224\end{array}$ & $\begin{array}{c}30.0 \\
32.5 \pm 1.66 \S\end{array}$ \\
\hline
\end{tabular}

* Significantly different $(P<0.01)$ from saline controls in Group I but not in Group II.

$\ddagger$ Elastase-treated animals received one intratracheal injection of $0.2 \mathrm{mg}$ of crystalline, porcine, pancreatic elastase $/ 0.5 \mathrm{ml}$ physiologic saline per $100 \mathrm{~g}$ body wt. $\S$ Significantly different $(P<0.005)$ from all control groups.

hamsters seems an acceptable albeit imperfect model of human chronic bronchitis.

Previous attempts to clarify the pathogenesis of chronic bronchitis and emphysema with animal models have included exposure to nitrogen dioxide (22), sulphur dioxide (23-26), isoprenaline $(27,28)$, cigarette smoke (29-36), and enzymes (9, 10, 37-39). These agents cause lung damage with varying similarity to human disease. Persistent goblet cell increase has been produced in rats for at least 5 wk after 2 wk of repeated exposure to $\mathrm{SO}_{2}(24)$ and in pigs for 2 mo after six daily injections of iso- prenaline (28). Emphysematous lesions have not been reported in $\mathrm{SO}_{2}$ or isoprenaline-treated animals. The present study shows that the hamster lung exposed to a single instillation of elastase develops not only a lesion with the morphological and some of the physiological characteristics of human panacinar emphysema (9-11), but also shows irreversible GCM. Relevant to this is the demonstration of GCM in the distal bronchioles of humans with chronic bronchitis and emphysema but not in those of subjects with bronchitis alone (40).

Why persisting GCM occurs after a single episode of 


\section{A}

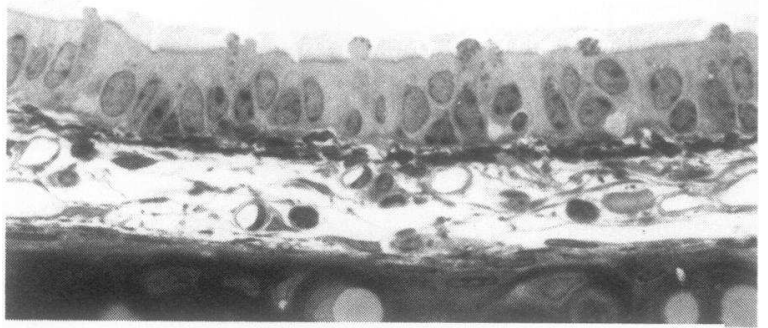

8

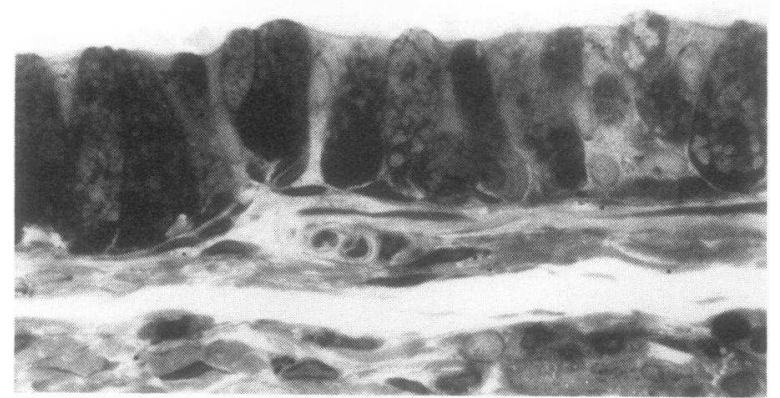

FIGURE 4 Photomicrographs of plastic-embedded tissue from perfusion-fixed lungs of hamsters killed 16 days after exposure to either saline (A) or $0.2 \mathrm{mg}$ pancreatic elastase $/ 100 \mathrm{~g}$ body wt (B). Note the large number of goblet cells bulging with secretory droplets in the treated lung compared with the control lung showing fewer goblet cells, none of which are swollen with secretory droplets (both $\times 510$ ).

elastase injury is obscure. It is an unusual pathological phenomenon because damaged epithelium tends to regenerate with restoration of the original architecture provided the general structure of the organ is preserved after injury. Thus, after denudation, gastric mucosa regenerates by passing through a stage of simple mucus-secreting tubular glands before the more complicated gastric structure is re-established (41). A similar repair pattern is followed in the damaged duodenum (42), while tracheal mucosa regenerates within $6 \mathrm{wk}$ after curettage (43). Persistence of the mucus-secreting stage after elastase exposure suggests either that the hamster bronchus responds differently to injury than do other mucosal surfaces, or that there is a continuing injury. The nature of such a continuing injury is conjectural but it could result from the release of enzymes from increased numbers of PML or AM in the airways over an extended period. In support of this possibility is the finding that lung washout fluid has an elevated content of PML for up to 60 days after elastase exposure (44).

Endogenous proteases have been implicated as possible causal agents of emphysema in patients with ATD (6-8) and in cigarette smokers (45). This contention is supported by the production of emphysemalike damage in mice exposed to an enzyme extract from human AM (46) and in dogs exposed to homogenates from human and dog PML and to dog AM (47). Neither experimental study reported a bronchial lesion. It is of interest that antiproteases different from known serum inhibitors have been discovered in various lung components including the peripheral airspaces of dogs (48), the cytosol of human AM (49), and human bronchial mucus from patients with severe chronic bronchitis (50). The source of bronchial antiprotease is unknown but conceivably could be derived from goblet cells. If this is so, GCM in elastase-exposed hamsters and in humans with emphysema and chronic bronchitis could represent a mechanism for raising the level of elastase inhibitor in the lung.

The rapid increase in the percentage of goblet cells by 1 day in elastase-treated animals and to a lesser extent in saline-treated animals may be due to a surge in mucus synthesis by undifferentiated epithelial cells, i.e. potential goblet cells, in response to an irritant. It seems unlikely that cell division and differentiation could occur rapidly enough to account for this precipitous increase in goblet cells. Repair of the saline injury by 33 days is not surprising given the normal rate of turnover of respiratory epithelium but the cause of the persisting elastase injury remains to be determined.

Whether the elastase-induced bronchial lesion has an effect in altering airway dynamics is not known. We have observed GCM with papain-induced emphysema in hamsters ${ }^{3}$ and have shown that the emphysema-inducing property of papain is related to its elastolytic activity (51). Several investigators (52-55) have studied lung function in papain-induced emphysema and with one exception in the dog (53), found that alterations in airways dynamics were due to loss of elastic recoil rather than to increased peripheral airways resistance. However, all of these studies were carried out relatively early in the course of the lesion and, as we have shown here, GCM persists for at least $1 \mathrm{yr}$ after the initial insult.

Our observation that a single dose of pancreatic elastase in hamsters causes permanent bronchial

${ }^{3}$ Unpublished observations. Hayes, J. A., and G. L. Snider. 
damage as well as progressive emphysema may have profound implications for man. A chronic disease process may occur when a threshold for permanent damage is approached gradually by repeated, intermittent contact with low concentrations of an injurious agent. Alternatively, such a threshold may be reached abruptly upon exposure to a single overwhelming dose of an appropriate agent. The elastase-induced lesions in hamsters may be considered an example of the latter instance. A parallel human situation may be the reported permanent loss of exercise tolerance after an acute chest illness in 5 of 23 patients with chronic obstructive lung disease associated with ATD (1). The bronchial and parenchymal damage resulting from a single insult with elastase may persist and worsen due to a disturbed balance in a possible endogenous protease-antiprotease system. In view of the physiological and pathological similarities between elastase-induced lung damage in hamsters and human panacinar emphysema with chronic bronchitis, the present study suggests that a permanent anatomic lesion in both the bronchus and lung parenchyma in man could result from a single enzymatic injury from whatever source. The further implication is that a single acute lung injury may induce chronic, progressive pulmonary disease.

\section{ACKNOWLEDGMENTS}

The authors wish to thank Ms. Michelle Speier for her assistance in preparation of the manuscript.

This study was supported by the National Heart and Lung Institute Pulmonary Special Center of Research grant HL-15063 and by the Veterans Administration Research Service.

\section{REFERENCES}

1. Eriksson, S. 1965. Studies in $\alpha_{1}$-antitrypsin deficiency. Acta Med. Scand. 177 (Suppl.): 432, 1-85.

2. Guenter, C. A., M. H. Welch, T. R. Russell, R. M. Hyde, and J. F. Hammarsten. 1968. The pattern of lung disease associated with alpha ${ }_{1}$ antitrypsin deficiency. Arch. Intern. Med. 122: 254-257.

3. Townley, R. G., F. Ryning, H. Lynch, and A. W. Brody. 1970. Obstructive lung disease in hereditary $\alpha_{1}$-antitrypsin deficiency. JAMA (J. Am. Med. Assoc.) 214: 325-331.

4. Orell, S. R., and P. Mazodier. 1972. Pathological findings in alpha ${ }_{1}$-antitrypsin deficiency. In Pulmonary Emphysema and Proteolysis. C. Mittman, editor. Academic Press Inc., New York. 69-89.

5. Hutchison, D. C. S., P. J. L. Cook, C. E. Barter, H. Harris, and P. Hugh-Jones. 1971. Pulmonary emphysema and $\alpha_{1}$-antitrypsin deficiency. Br. Med. J. 1: 689-694.

6. Lieberman, J. 1973. Involvement of leukocytic proteases in emphysema and antitrypsin deficiency. Arch. Environ. Health. 27: 196-200.

7. Cohen, A. B. 1973. Interrelationships between the human

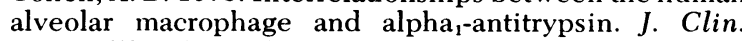
Invest. 52: 2793-2799.
8. Galdston, M., A. Janoff, and A. L. Davis. 1973. Familial variation of leukocyte lysosomal protease and serum $\alpha_{1-}$ antitrypsin as determinants in chronic obstructive pulmonary disease. Am. Rev. Respir. Dis. 107: 718-727.

9. Kaplan, P. D., C. Kuhn, and J. A. Pierce. 1973. The induction of emphysema with elastase. I. The evolution of the lesion and the influence of serum. J. Lab. Clin. Med. 82: 349-356.

10. Hayes, J. A., A. Korthy, and G. L. Snider. 1975. The pathology of elastase-induced panacinar emphysema in hamsters. J. Pathol. 117: 1-14.

11. Sherter, C. B., K. W. Koo, J. A. Hayes, D. E. Leith, C. Franzblau, and G. L. Snider. 1974. Serial lung volumes and mechanics in elastase-induced emphysema. Clin. Res. 22: 718 (Abstr.)

12. Wright, R. R. 1968. Suggested criteria for confirming pulmonary emphysema in the experimental animal. Yale J. Biol. Med. 40: 576-578.

13. Siegel, S. 1956. Nonparametric Statistics for the Behavioral Sciences. McGraw Hill Co., New York 312 p.

14. Karnovsky, M. J. 1965. A formaldehyde-glutaraldehyde fixative of high osmolality for use in electron microscopy. J. Cell Biol. 27: 137-138. (Abstr.)

15. Schefler, W. C. 1969. Statistics for the Biological Sciences. Addison-Wesley Publishing Co., Inc., Reading, Mass.

16. CIBA Guest Symposium Report. 1959. Terminology, definitions and classification of chronic pulmonary emphysema and related conditions. Thorax. 14: 286-299.

17. American Thoracic Society. 1962. Chronic bronchitis, asthma and pulmonary emphysema. A statement by the committee on Diagnostic Standards for Nontuberculous Respiratory Diseases. Am. Rev. Respir. Dis. 85: 762768.

18. Hayes, J. A. 1969. Distribution of bronchial gland measurements in a Jamaican population. Thorax. 24: 619-622.

19. Thurlbeck, W. M., G. E. Angus, and J. A. P. Paré. 1963. Mucous gland hypertrophy in chronic bronchitis, and its occurrence in smokers. Br. J. Dis. Chest. 57: 73-78.

20. Thurlbeck, W. M., and G. E. Angus. 1963. The relationship between emphysema and chronic bronchitis as assessed morphologically. Am. Rev. Respir. Dis. 87: $815-819$.

21. Thurlbeck, W. M. 1976. Chronic Airflow Obstruction in Lung Disease. W. B. Saunders Company, Philadelphia, Pa. 31-46.

22. Freeman, G., and G. B. Haydon. 1964. Emphysema after low-level exposure to $\mathrm{NO}_{2}$. Arch. Environ. Health. 8: 125-128.

23. Reid, L. 1963. An experimental study of hypersecretion of mucus in the bronchial tree. Br. J. Exp. Pathol. 44: 437-445.

24. Lamb, D., and L. Reid. 1968. Mitotic rates, goblet cell increase and histochemical changes in mucus in rat bronchial epithelium during exposure to sulphur dioxide. J. Pathol. Bacteriol. 96: 97-111.

25. Spicer, S. S., L. W. Chakrin, and J. R. Wardell. Jr. 1974. Effect of chronic sulfur dioxide inhalation on the carbohydrate histochemistry and histology of the canine respiratory tract. Am. Rev. Respir. Dis. 110: 13-24.

26. Goldring, I. P., L. Greenburg, S.-S. Park, and I. M. Ratner. 1970. Pulmonary effects of sulfur dioxide exposure in the Syrian hamster. II. Combined with emphysema. Arch. Environ. Health. 21: 32-37.

27. Sturgess, J., and L. Reid. 1973. The effect of isoprenaline and pilocarpine on (a) bronchial mucus-secreting tissue and (b) pancreas, salivary glands, heart, thymus, liver and spleen. Br. J. Exp. Pathol. 54: 388-403. 
28. Baskerville, A. 1976. The development and persistence of bronchial-gland hypertrophy and goblet-cell hyperplasia in the pig after injection of isoprenaline. J. Pathol. 119: $35-47$.

29. Holland, R. H., E. J. Kozlowski, and L. Booker. 1963. The effect of cigarette smoke on the respiratory system of the rabbit. A final report. Cancer. 16: 612-615.

30. Hernandez, J. A., A. E. Anderson, Jr., W. L. Holmes, and A. G. Foraker. 1966. Pulmonary parenchymal defects in dogs following prolonged cigarette smoke exposure. Am. Rev. Respir. Dis. 93: 78-83.

31. Rockey, E. E., and F. D. Speer. 1966. The ill effects of cigarette smoking in dogs. Int. Surg. 46: 520-530.

32. Auerbach, O., E. C. Hammond, D. Kirman, and L. Garfinkel. 1967. Emphysema produced in dogs by cigarette smoking. JAMA (J. Am. Med. Assoc.) 199: 241-246.

33. Frasca, J. M., O. Auerbach, V. R. Parks, and J. D. Jamieson. 1968. Electron microscopic observations of the bronchial epithelium of dogs. II. Smoking dogs. Exp. Mol. Pathol. 9: 380-399.

34. Lamb, D., and L. Reid. 1969. Goblet cell increase in rat bronchial epithelium after exposure to cigarette and cigar tobacco smoke. Br. Med. J. 1: 33-35.

35. Jones, R., P. Bolduc, and L. Reid. 1973. Goblet cell glycoprotein and tracheal gland hypertrophy in rat airways: the effect of tobacco smoke with or without antiinflammatory agent phenylmethyloxadiazole. Br. J. Exp. Pathol. 54: 229-239.

36. Mawdesley-Thomas, L. E., and P. Healey. 1973. Experimental bronchitis in lambs exposed to cigarette smoke. Arch. Environ. Health. 27: 248-250.

37. Gross, P., E. A. Pfitzer, E. Tolker, M. A. Babyak, and M. Kaschak. 1965. Experimental emphysema. Its production with papain in normal and silicotic rats. Arch. Environ. Health. 11: 50-58.

38. Goldring, I. P., L. Greenburg, and I. M. Ratner. 1968. On the production of pulmonary emphysema in Syrian hamsters by aerosol inhalation of papain. Arch. Environ. Health. 16: 59-60.

39. Weinbaum, G., V. Marco, T. Ikeda, B. Mass, D. R. Meranze, and P. Kimbel. 1974. Enzymatic production of experimental emphysema in the dog. Route of exposure. Am. Rev. Respir. Dis. 109: 351-357.

40. Thurlbeck, W. M., D. Malaka, and K. Murphy. 1975. Goblet cells in the peripheral airways in chronic bronchitis. Am. Rev. Respir. Dis. 112: 65-69.

41. Jennings, M. A., and H. W. Florey. 1970. Healing. In General Pathology. H. W. Florey, editor. W. B. Saunders Company, Philadelphia, Pa. 4th Edition. 517-519.

42. Florey, H. W., and H. E. Harding. 1935. The healing of artificial defects of the duodenal mucosa. J. Pathol. Bacteriol. 40: 211-218.

43. Wilhelm, D. L. 1953. Regeneration of tracheal epithelium. J. Pathol. Bacteriol. 65: 543-550.

44. Kovnat, D. M., G. L. Snider, and J. S. Brody. 1975. Pattern of injury and phagocytic function in elastase induced emphysema. Clin. Res. 23: 349. (Abstr.)

45. Harris, J. O., G. N. Olsen, J. R. Castle, and A. S. Maloney. 1975. Comparison of proteolytic enzyme activity in pulmonary alveolar macrophages and blood leukocytes in smokers and nonsmokers. Am. Rev. Respir. Dis. 111: 579-586.

46. Janoff, A. 1972. Anatomic emphysema produced in mice by lysosome-containing fractions from human alveolar macrophages. Fed. Proc. 31: 254 (Abstr.)

47. Mass, B., T. Ikeda, D. R. Meranze, G. Weinbaum, and P. Kimbel. 1972. Induction of experimental emphysema. Cellular and species specificity. Am. Rev. Respir. Dis. 106: 384-391.

48. Weinbaum, G., M. Takamoto, B. Sloan, and P. Kimbel. 1976. Lung antiprotease: a potential defense against emphysema development. Am. Rev. Respir. Dis. 113: 245-248

49. Blondin, J., R. Rosenberg, and A. Janoff. 1972. An inhibitor in human lung macrophages active against human neutrophil elastase. Am. Rev. Respir. Dis. 106: 477-479.

50. Rasche, B., K. Hochstrasser, I. Marcic, and W. T. Ulmer. 1975. Schleimhautspezifische Proteaseinhibitoren im Bronchialschleim bei schwerer chronisch obstruktiver Bronchitis und bei $\alpha_{1}$-Antitrypsinmangelsyndrom. Respiration. 32: 340-354.

51. Snider, G. L., J. A. Hayes, C. Franzblau, H. M. Kagan, P. S. Stone, and A. L. Korthy. 1974. Relationship between elastolytic activity and experimental emphysema-inducing properties of papain preparations. Am. Rev. Respir. Dis. 110: 254-262.

52. Park, S. S., I. P. Goldring, C. S. Shim, and M. H. Williams, Jr. 1969. Mechanical properties of the lung in experimental pulmonary emphysema. J. Appl. Physiol. 26: $738-744$.

53. Pushpakom, R., J. C. Hogg, A. J. Woolcock, A. E. Angus, P. T. Macklem, and W. M. Thurlbeck. 1970. Experimental papain-induced emphysema in dogs. Am. Rev. Respir. Dis. 102: 778-789.

54. Caldwell, E. J. 1971. Physiologic and anatomic effects of papain on the rabbit lung. J. Appl. Physiol. 31: 458465.

55. Niewoehner, D. E., and J. Kleinerman. 1973. Effects of experimental emphysema and bronchiolitis on lung mechanics and morphometry. J. Appl. Physiol. 35: 25-31. 